\title{
Standardization of the Rorschach Test among drug addicted people
}

\section{Parastoo Hassan Beygi ${ }^{1}$}

1-M.Sc Clinical Psychology, Department of Psychology, Islamic Azad University of Sanandaj Branch, Sanandaj, Iran (Corresponding Author). ORCID: 0000-0001-6434-6113 E-mail: parastohasanbeigi@Gmail.com

$$
\text { Received: 28/04/2019 }
$$

Accepted: 11/09/2019

\begin{abstract}
Introduction: Addiction is a social phenomenon whose extent of damage and destruction among community members is much greater than other social damage.

Aim: The present study was conducted to determine the norms of Rorschach test among drug addicts. The statistical population of the present study, addicted drug addicts in addiction treatment centers in Qorveh city in 1396 were to number 30 people who were examined through Rorschach test.

Method: The method of the present research has been Fundamental-Applied in terms of purpose, in terms of strategy, of type descriptive, and in terms of data analysis, was of type content analysis.

Results: The findings of the study showed that drug addicts people had a disorder in the defect in compromise and toleration profiles with an average of 5, Perception-Thinking index with an average of 4 and the index of obsessive-compulsive disorder with an average of 4 . EA index with mean of 5, es \& Adj es an average of 10, D \& Adj D with an average of -1 and EBPer with N/A score had a significant difference with other indices.

Conclusion: The results indicative the presence of stress, obsession, inhibition of emotions, negative introspection, weak social relationships and poor processing of information in them. These people, due to their inflexible thinking and values, have been mistaken in judging and making decisions and take refuge to fantasy for deny reality and facing the annoying position. Keywords: Standardization, Rorschach, Addiction, Drugs
\end{abstract}

How to cite this article : Hassan Beygi P. Standardization of the Rorschach Test among drug addicted people. Shenakht Journal of Psychology and Psychiatry. 2019; 6 (4): 68-79 .URL: http://shenakht.muk.ac.ir/article-1-639-fa.pdf

Copyright $(92018$ the Author (s). Published by Kurdistan University of Medical Sciences. This is an open access article distributed under the terms of the Creative Commons Attribution-Non Commercial License 4.0 (CCBY-NC), where it is permissible to download, share, remix, transform, and buildup the work provided it is properly cited. The work cannot be used commercially without permission from the journal. 


\title{
هنجاريابى آزمون رورشاخ در بين افراد معتاد به مواد مخدر
}

\author{
يرستو حسن بيكى' \\ ا.كارشناسى ارشد روانشناسى بالينى، گروه روانشناسى، دانشكاه آزاد اسلامى واحد سندج، سندج، ايران (مولف مسئول). \\ ايميل: parastohasanbeigi@Gmail.com
}

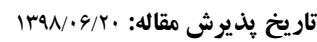

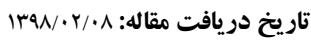

جكيده

مقدمه: اعتياد يديدهاى است اجتماعى كه دامنهى آسيبرسانى و تخريب آن در ميان افراد جامعه نسبت به آسيبهاى اجتماعى ديخر، بسيار كستردهتر است.

هدف: يززوهش حاضر با هدف تعيين هنجارهاى آزمون رورشاخ در بين افراد معتاد به مواد مخدر انجام گرفت. جامعه آمارى

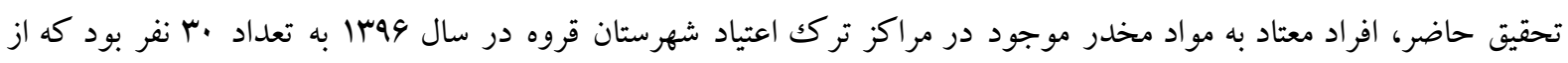
طريق آزمون رورشاخ مورد بررسى قرار خرفتند. روش: روش تحقيق حاضر از نظر هدف بنيادى- كاربردى بوده، از نظر استراتزى، از نوع توصيفى و از نظر تجزيهوتحليل داده ها، از نوع تحليل محتوا بود.

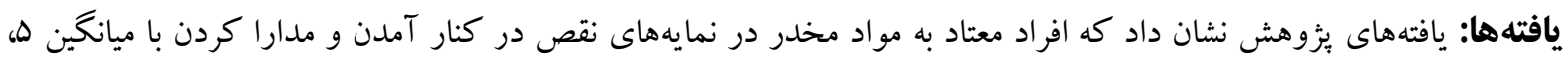

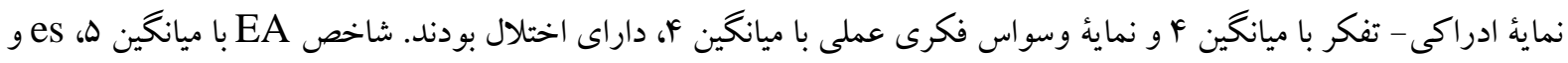

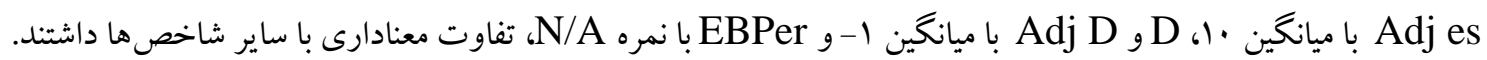
نتيجه كيرى: نتايج بهدست آمده حاكى از وجود استرس، وسواس، بازدارى هيجانات، درون نخرى منفى، روابط اجتماعى ضعيف و يردازش ضعيف اطلاعات در آنهاست. اين افراد به دليل تفكر و ارزشهاى انعطاف نايذير، دجار خطا در قضاوت و

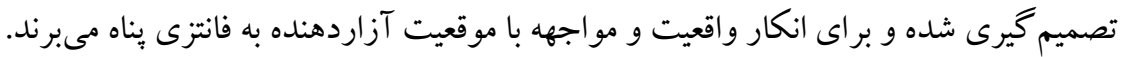
كليد وازهها: هنجاريابى، رورشاخ، اعتياد، مواد مخدر 
فنون فرافكن به طور غيرمستقيم كوشش در راه يابى به

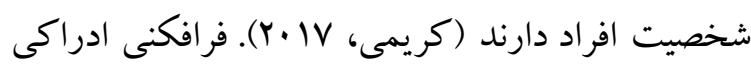
نوعى از فرافكنى است كه با آزمون لكههاى جوهر

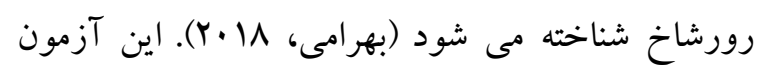

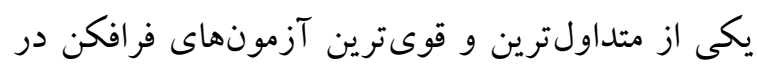

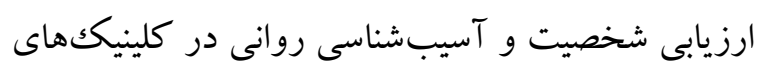
روانشناسى و روانيزشكى است (رحمانى به نقل از

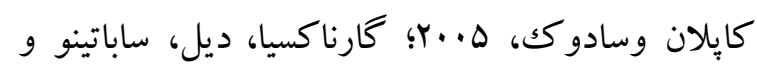

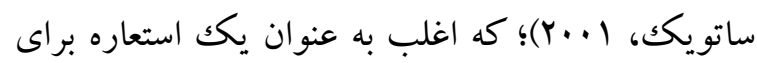

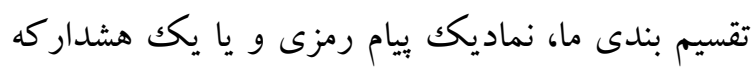

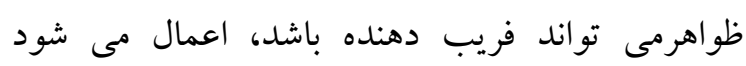

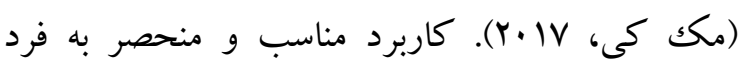

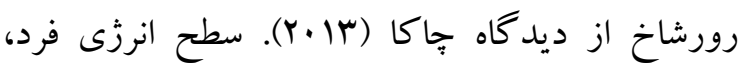
كنترل احساسات و فرآيند افكار را نشان مى دهد، جيزى كه ساير آزمونها قادر به انجام آن نيستند. هدف كلى آزمون، سنجش ساختار شخصيتى مراجع با تأكيد بر شيوهاى ناهشيار وى در باسخ دادن به محيط خود و

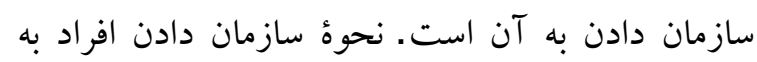

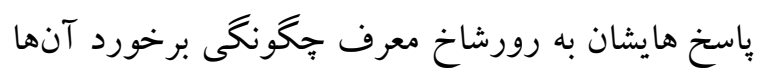
با ساير موقعيتهاى مهم است كه مستلزم سازمان دادن

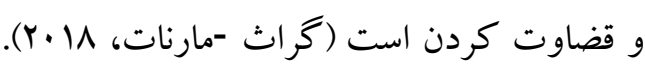
به نظر طرفداران اين آزمون، تحليل هاى محتوايى و آمارى نمرات به دست آمده از آن، اطلاعات بالينى

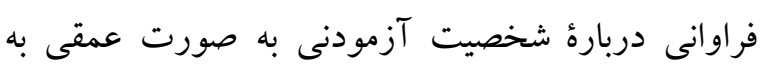
دست مىدهد. علاوه بر اين نتيجه گيرىهايى در مورد تكانها و نيروهاى كنترل كننده، حوزههاى تعارض،

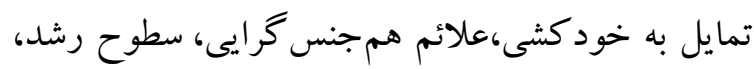

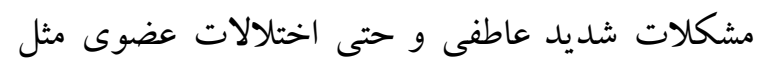

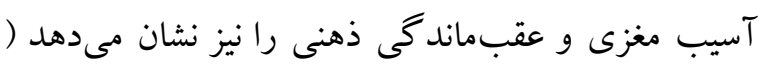

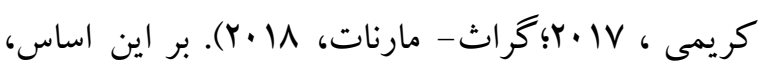
هنجارهاى اوليه براى عقب ماند كان ذهنى، افراد بهنجار،

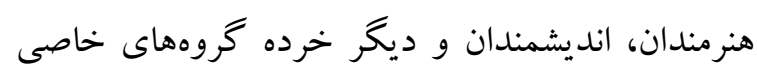

\section{مقلdمه}

براى بعضى افراد، اعتياد منبع انخيزشى نيرومندى است

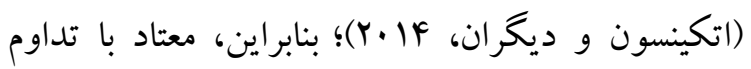
مصرف ازنظر ظاهرى و رفتارى به تعريف صورى معتاد در جامعه شبيه شده، آرام آرام هنجارهاى جامعنه معتادين و فرهنگك متعلق به ايشان را مى يذيرد و در نتيجه امنها مصداق برجسبى مى شود كه معتاد نام دارد. روانشناسان و به طور كلى محققين آمادكى روانى و شخصيت ناهنجار شخص را علت اصلى ابتلا به اعتياد مىدانند.

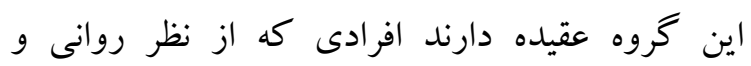

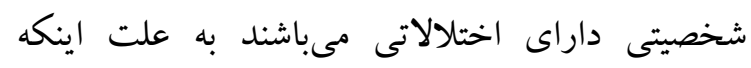

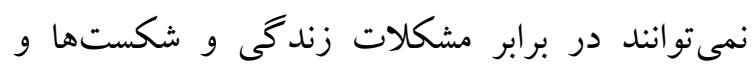

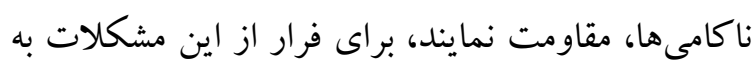

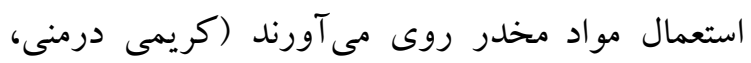
. (Y.) V مسلم است كه همة افراد آن نوع شخصيتى را كه در عمل بتواند نقش معينى را ايفا كند، ندارند. به اين

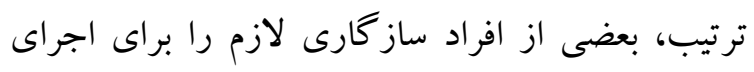

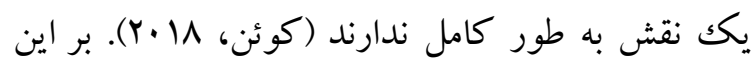
اساس، روان شناسان بالينى مى كوشند به وسيله سنجيدن

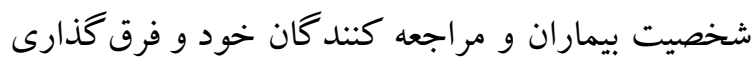
بين رفتارها و احساسهاى بهنجار و نابهنجار، نشانههاى

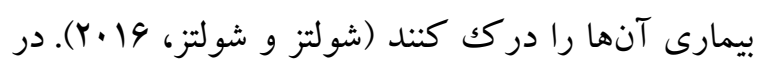
اين راستا، بسيارى از روانشناسان، از جمله آنها كه كرايش روان يويشى دارند، در سنجش شخصيت آدمى،

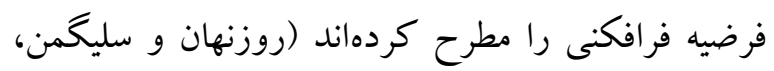
.$(Y .19$

بر اساس فرضيه فرافكن، هنگًامى كه محرك هاى مبهم نظير شكل هاى لكه جوهر، به آزمودنى ارائه مى شود، محدوديت هاى واقعيت به حداقل مى رسد، فر آيندهاى تخيلى ترغيب شده و فرصت نمايان شدن تعارضات ناهشيار به حداكثر مىرسد (روزنهان و سليگمن، 19 (r). 
بالاترى از دانشجويان بهنجار ارائه مى دهند. آنها ياسخهاى وابستكى دهانى بيشترى به رورشاخ دادند. نتايج

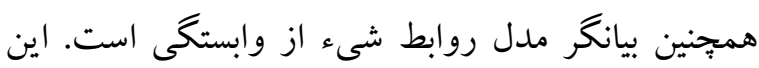
نياز به وابستخى تصديق شده اما غلبه بر آن نيست و بيشتر

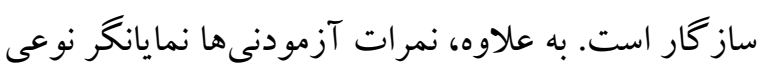
پاسخ دفاعى كلى و وجود تظاهرات فرآيند اوليه در محتويات رورشاخ بود. يروتكل آزمون در يُزوهش

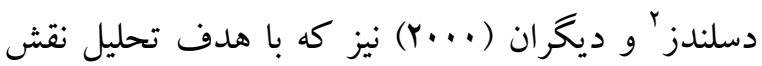
تخيل و ارتباط آن با واقعيت در ميان معتادان به هروئين بود، نشان دهنده شيوه سازمان نيافتهُ تأثير تخيل تصويرى

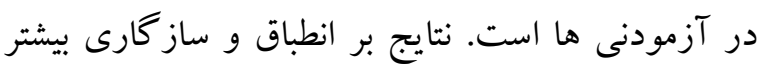
آن ها متكى است كه سعى در كنار كذاشتن اين تخيل را دارند؛ اما اين فعاليت ذهنى خاص، نتوانست با فقدان فانتزى مشاهده شده در معتادان به هروئين، وفق داده شود.

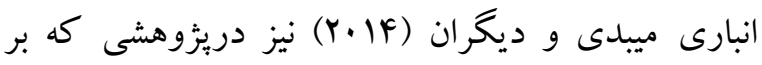
روى گروه وابسته به مت- آمفتامين انجام داده بودند

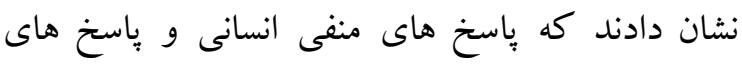
رنگك- شكل در آزمون رورشاخ، قادر بودند به طور معنى دارى افراد وابسته به مت- آمفتامين را از گروه

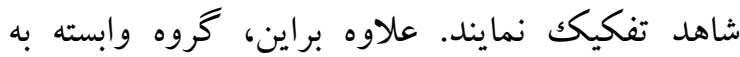

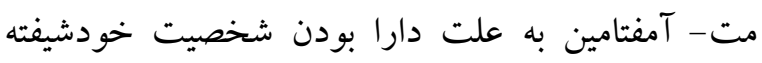
تا حدى در مورد كمال شخصى نامطمئن بودند و تمايل داشتند موقعيت هايى را كه با ارزش خودجالش انخيزمى يابند، با حالت تدافعى خنثى يا كنترل نمايند. عدم شناسايى اين هنجارها، مشكلات عديدهاى را براى

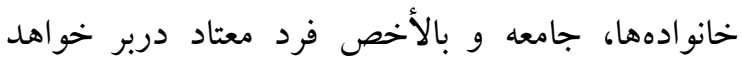
داشت؛ تعداد دانش آموزان در معرض خطر اعتياد به مواد مخدر افزايش خواهد يافت، به جمعيت معتادين روز به روز افزوده خواهد شد، سن ابتلا به اعتياد كاهش خواهد يافت، جمعيت زندانيان معتاد به مواد
كه داراى مشخصات شناخته شده بودند تدوين گرديد

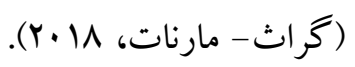

حال، نخستين برسشى كه مطرح مىشود اين است كه

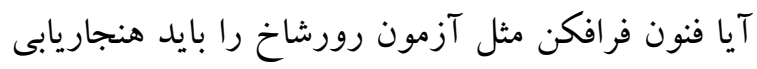
كنيم؟ بى شك دلايل زيادى براى اين كار وجود دارد دارد.

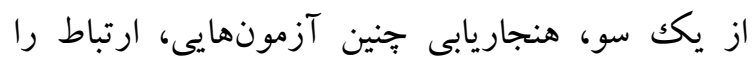
تسهيل مى كند و جلوى سو گيرىها و تعصبات تفسيرى برخى روانشناسان بالينى را مى گيرد (ترال و يرينستين،

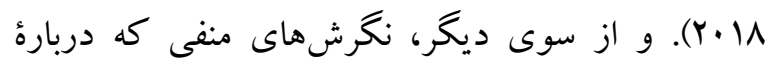
اين آزمون به وجود آمده است، منجر به كاهش تعداد كارتهاى اداره شده ، كاهش تعداد متغيرهايى كه به به دست آوردهاند و هم جنين مديريت تعاملى و محدودتر آزمون شده است (جاكا، 19 19). بر همين اساس ئزوهشهاى زيادى در خارج از كشور در خصوص هنجاريابى آزمون رورشاخ در بين معتادين صورت گرفته است اما بيشتر اين تحقيقات در مورد مورد معتادين به الكل بوده و تاكنون در ايران در مورد معتادين به مواد مخدر هنجارى شناسايى نشده است. براى مثال، تحقيقات انجام شده اكسنر و ديخران (19VV) بر روى معتادين به مواد مخدر نشان داد كه شاخص (حرزمان محدوديتهاى فيزيكى (FM) در ميان فواحش معتاد به مواد مخدر افزايش مىيابد. اين افزايش نشانه تكانهاى بازدارى نشدهُ هيجانى و

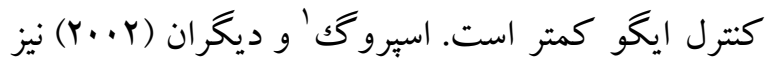
يزوهشى با هدف بررسى تجربى رابطه الكليسم با نظريه

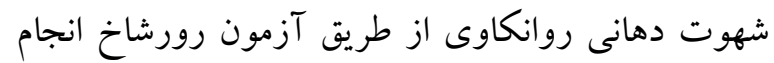

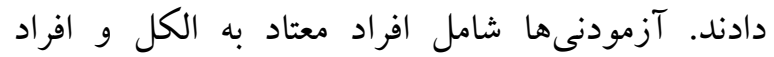
افسردهاى بود كه با دانشجويان كارشناسى ارشد بهنجار

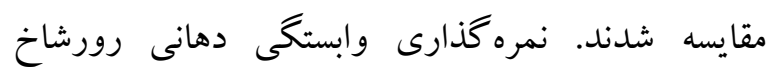
ROD نشان داد كه آزمودنى ها نمرات (ROD) 
لكه ها رنكى و تعدادى سياه و سفيد هستند. آزمودنى

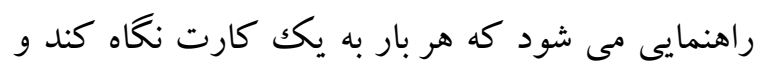
كزارش دهد كه شبيه جه جيزهايى است (اتكينسون و و

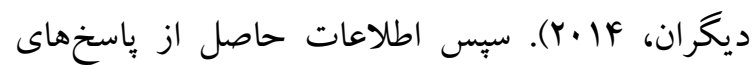
آزمودنىها به روش بر گه كد گذارى جمع آورى شده

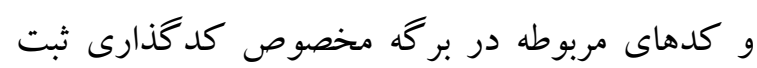

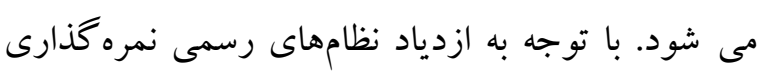

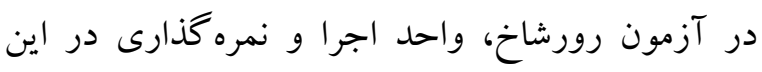

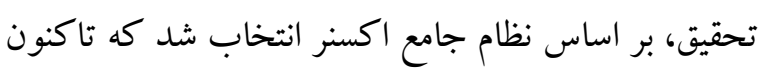

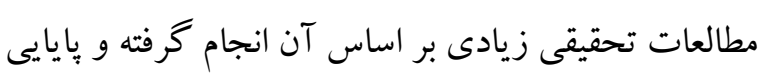

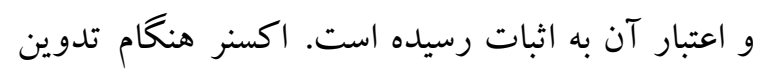
نظام جامع خود براى تدوين طبقه هاى مختلف نمره

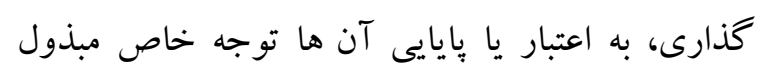

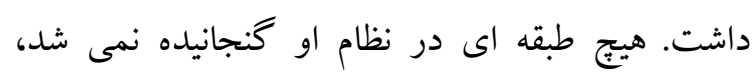

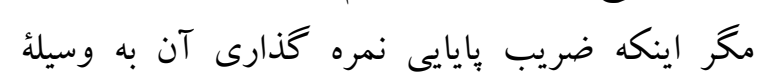
ارزياب هاى مختلف دست كم به هA/ • برسد (اكسنر، (9Vץ ) گسترده ى مطالعات صورت گرفته درباره ى رورشاخ

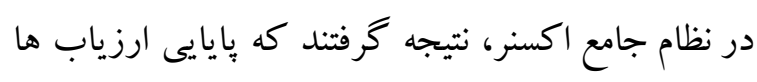

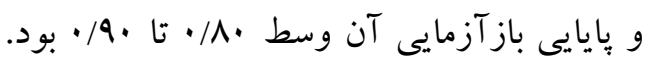

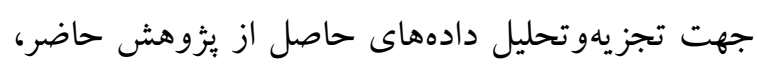
از روش تحليل محتوا استفاده شد كه يكى از روشهاى دهای

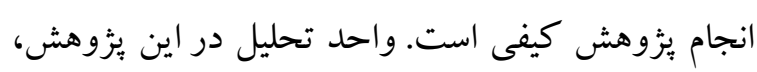

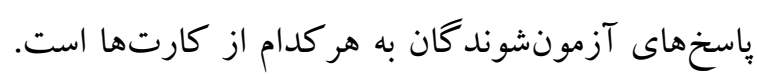
بدينصورت كه جدولى تهيه شد كه بر اساس منابع

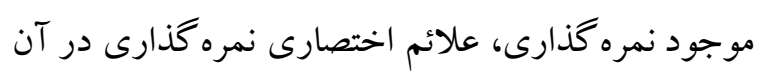
نوشته شد و براساس نظام جامع اكسنر تدوين كرديد.

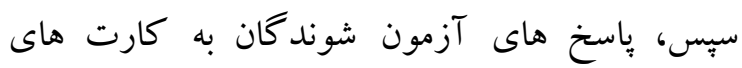

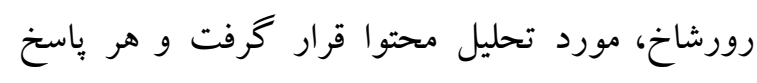
مناسب هر علائم به عنوان كد در آن نوشته شد. تمامى مورد

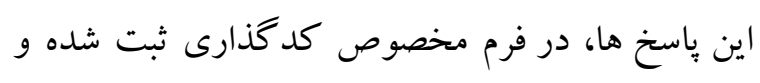

مخدر افزايش مى يابد، بهداشت و سلامت افراد و جامعه با خطر جدى مواجه خواهد شد و باعث متلاشى شدن خانوادهاى بيشترى خواهد خرديد (صديق سروستانى،

بر اين اساس، ضرورت اجراى اين ئزوهش در جامعه به

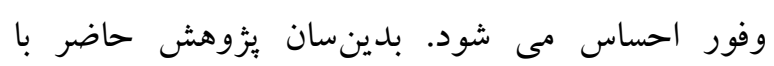
شناسايى هنجارهاى موجود در بين معتادين به مواد مخدر

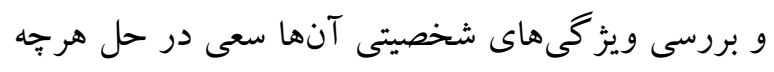

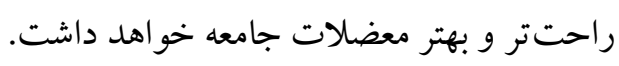
يثزوهش حاضر از نظر هدف از نوع بنيادى- كاربردى

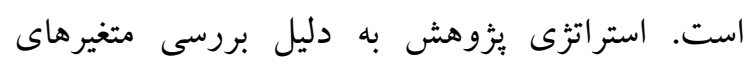

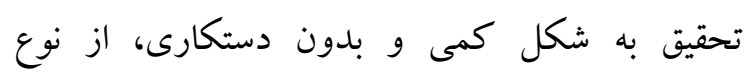
توصيفى انتخاب شد و جون متغيرهاى تحقيق در اسناد و

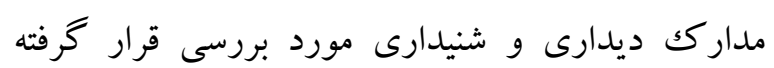

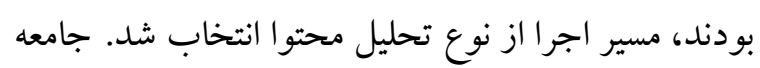

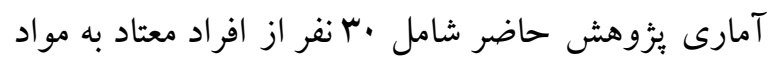
مخدرى بودندكه به مراكز تركك اعتياد شهرستان قروه در سال وهسا جهت ترك اعتيادشان مراجعه كرده بودند. نمونه مورد نظر، از يكك طرف به دليل حجم كم جامعه

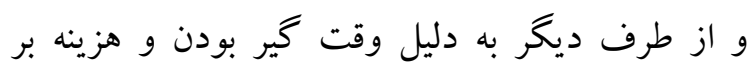
بودن آن با توجه به هدف آزمون كه تشخيص

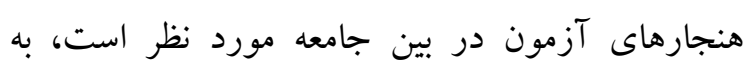
روش در دسترس انتخاب شدند.

ابزار آزمون لكه جوهر رورشاخ: براى اندازهيرى

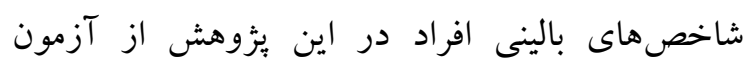

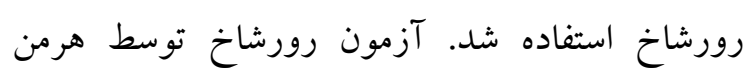
رورشاخ (·19Y) ساخته شد. اين آزمون شامل ده كارت و هر كارت شكل بييجيده لكه جوهر است. بعضى از 
به كارتها را نشان داده، بدينسان و با توجه به نتايج جدول ميانگين خلاصه ساختارى، شاخص D بيشترين ياسخ را دربرداشته و يس از آن Dd و Wd در مرتبه بعدى

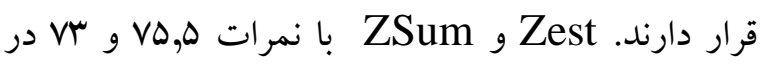

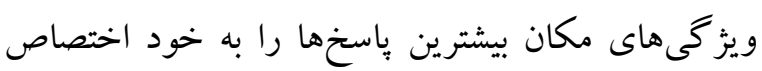

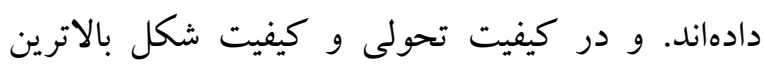
نمرات به شاخص O Oياسخ معمولى) مربوط است. يافته هاى جدول همجِنين بيانكر آن است كه در بين تعيين كننده ها F و FĆ و دور بين محتوا A و A ياسخها را دربردارند.
با توجه به تحليل محتوا و كدگذارى مورد نظر به سؤ الهاى يثزوهش باسخ داده شد.

يافتهها

هدف اين ئزوهش شناسايى هنجارهاى آزمون رورشاخ

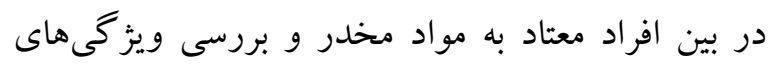

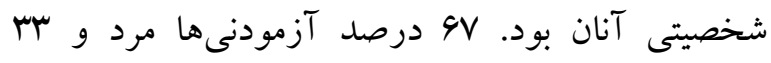

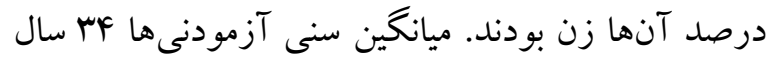
و انحراف استاندارد ץ بود. جدول ا ميانگين بيشترين ياسخهاى افراد معتاد به مواد مخدر به كارتهاى ده كانه، به ترتيب ارائه باسخ ها به هر كارت را نشان مى دهد. اين جدول، توالى انتخاب هاى مكان بِاسخ هاى آزمودنى ها به هـ

جدول ا خلاصه رويكرد

\begin{tabular}{lcccc}
\hline I: Dd .DS .W.D & II: D.W.Dd & III: D.W.Dd .DS & IV: W.WS .D .Dd & V: W. D. Dd \\
VI: W. Dd. D & VII: Dd .D.DS & VIII: Dd .S.D.W & IX: W.D.DS & X: Dd .D.W.WS
\end{tabular}

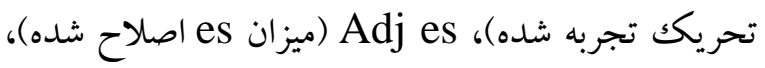

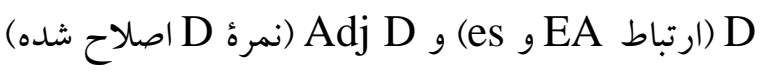

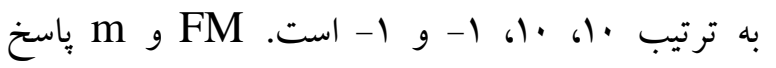

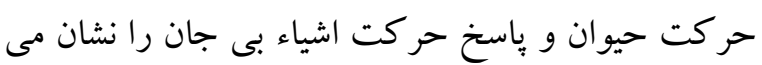
دهند. Sum Y و SumV ، Sum T ، SumC تأثير تعيين كنندهاى رنغك بى فام، بافت، حشم انداز و و و سايه روشن رادر ياسخهاى آزمودنىها بيان مى كند.
در جدول Y ، ميز ان درصدها و اشتقاقها مربوط به جامعه هدف، ارائه شده است. همانطور كه در اين جدول مشاهده مى شود، EB (نوع تجربه)، eb (تجربه يايه) و EA شاخص EBPer به تسلط سبك EB EB در فرآيند تصميم گيرى اشاره دارد كه N/A در اين شاخص نشان دهنده غيرقابل محاسبه بودن EBPer است. es (ميزان

\section{جدول r ميانكين نسبتها، درصدها و اشتقاقها}

\begin{tabular}{|c|c|c|c|c|c|}
\hline & R: $r V$ & & L: $/ / \wedge$ & & \\
\hline EB & $=r: r$ & EA & $=0$ & EBPer & $=\mathrm{N} / \mathrm{A}$ \\
\hline eb & $=r: \Lambda$ & es & $=1$. & D & $=-1$ \\
\hline & & Adj es & $=1$. & Adj D & $=-1$ \\
\hline FM & $=1$ & SumĆ & $=\wedge$ & Sum T & $=$. \\
\hline m & $=1$ & SumV & $=$ & Sum Y & $=$. \\
\hline
\end{tabular}


HVI, S-CON, CDI, DEPI, PTI

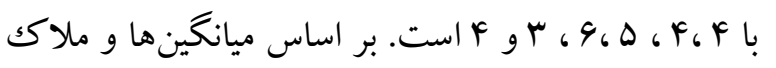
ها افراد با اعتياد به مواد مخدر در منظومههاى رفتارى ادراكى- تفكر، نقص در كنار آمدن و مدارا كردن و سبك وسواس فكرى عملى دجار مشكل بودند.
در جدول سا، با استفاده از آزمون رورشاخ و با توجه به

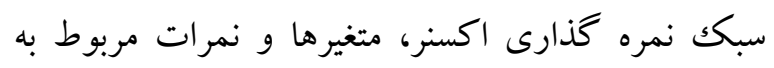
آنها در افراد معتاد به مواد مخدر آورده شده است. اين

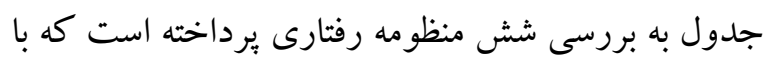

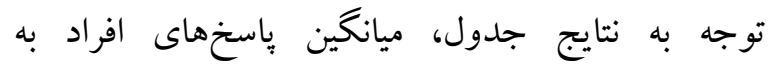

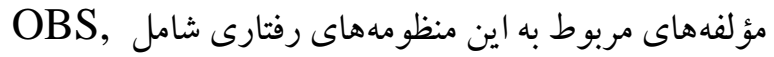

جدول بلاصه نمايهها

\begin{tabular}{|c|c|c|c|c|c|}
\hline نمايه ادراكى - تفكر & نمايه افسردكى & نمايه نقص كنار & خود مشظى مهى & زمايه كوش به بودن & نمايه سبكى \\
\hline حداكثر ب مورد & حداكثر ه مورد & حداكثر F مورد & حداكثر ^مورد & حداكثر F مورد & حداكثر بَ مورد \\
\hline $\mathrm{PTI}=\uparrow \nabla$ & DEPI $=\kappa \square$ & $\mathrm{CDI}=\Delta \square$ & $\mathrm{S}-\mathrm{CON}=9 \square$ & $\begin{array}{c}=r \mathrm{No} \square \\
\text { HVI }\end{array}$ & $\begin{array}{c}\text { OBS }=\varphi \\
\text { Yes } \square\end{array}$ \\
\hline
\end{tabular}

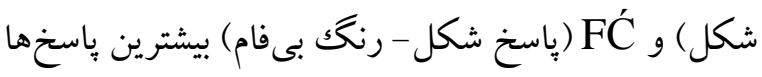

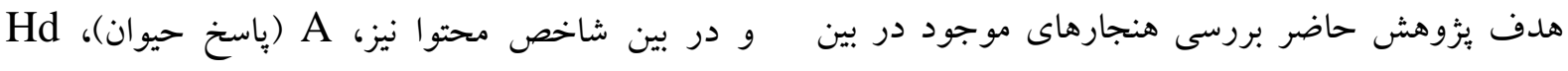

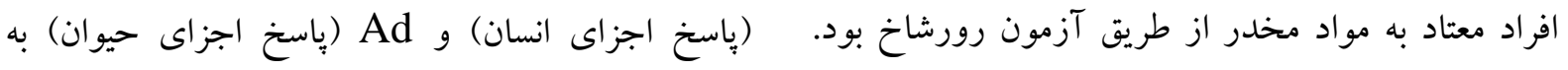

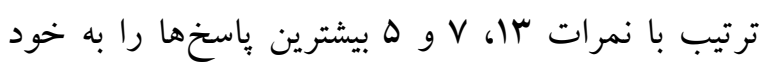

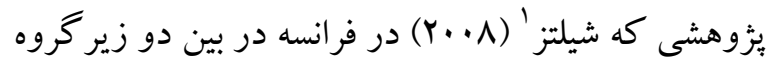

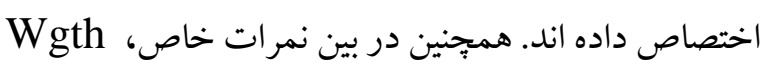

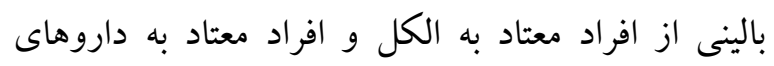
RAW Sum6 و Rum6 غيرمجاز انجام داد، بازتابى از واكنش شخصيت اصلى

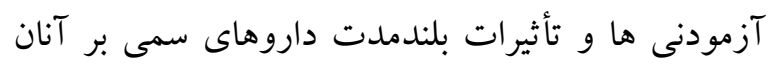

يافتهاى جدول ا بيانكر آن است كه آزمودنىها به هر

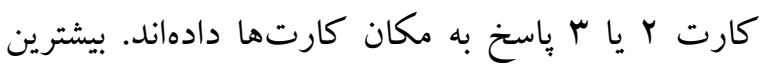
بر اين اساس، يافته هاى جدول خلاصهُ ساختارى حاكى ياسخها در انتخاب اول Wd و Dd در انتخاب دوم D و

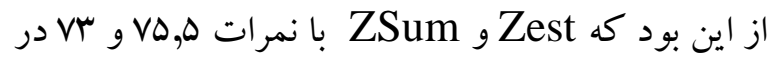

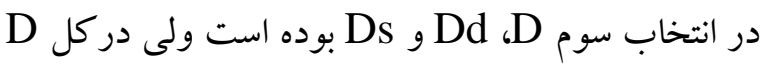

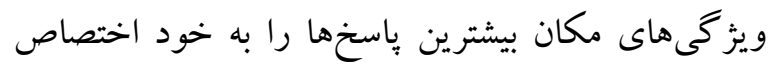

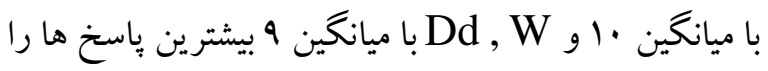

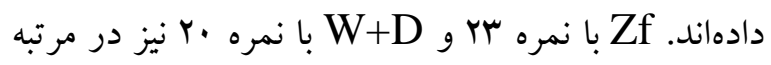

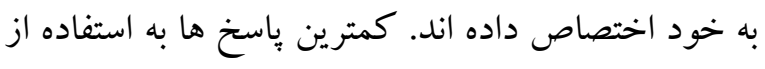
بعدى قرار دارند. در شاخص كيفيت تحولى، Oياسخ فضاى سفيد (S) با ميانگين Y بوده است. نتايج اين معمولى) و V (ياسخ مبهم) و در شاخص كيفيت شكل،

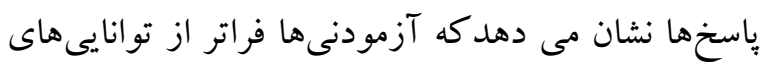
O خود، تلاش زيادى مى كنند تا كارها را به اتمام برسانند. نمرات را دارا هستند. در بين تعيين كنندها، F (ياسخ اكر دامنه اين گرايش، به رفتارهاى روزمره كشيده شود،

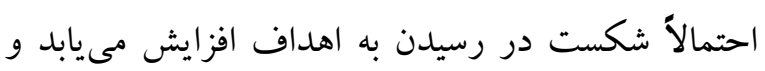


ضعيف، در تعاملات خود با محيط اغلب تجربه شكست و

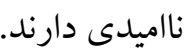

نمره ه درEA نشانگر ميزان تجربه واقعى بوده و نمره • در شاخص es بيانگر ميزان بالاى تحريك تجربه شده

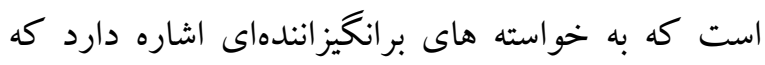
آزمودنى در حال حاضر تجربه مى كند. بر اين اساس، خود انكاره يا خود ارزشى در آزمودنى ها به طور كسترده اى برمبناى برداشت هاى خيالى يا تحريف تجربه واقعى

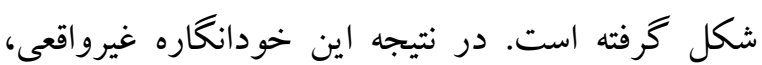
برآورد دقيق و صحيحى از نقاط ضعف و قوت خود

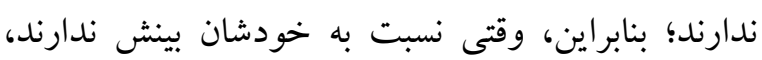
نمى تو انند نسبت به ديخر ان برداشت درستى داشته باشند. علامت N/A در شاخص EBPer نمايانكر EB فر تراكير است كه به تسلط سبك EB در فرايند تصميم گيرى اشاره دارد كه N/A در اين بروتكل، نشاندهنده غيرقابل محاسبه بودنEBPer است. اين يافته حاكى از اين است

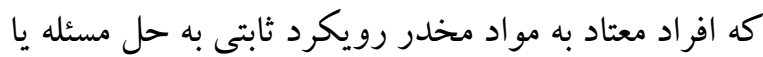
تصميم گيرى ندارند. يكى از نتايج اين حالت اين است

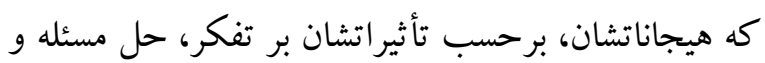

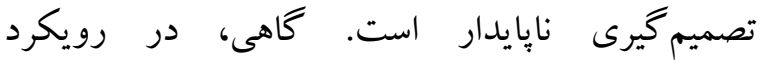

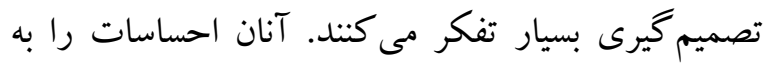
كنارى مىنهند و تمايل دارند تا تصميم گيرى را تا زمانى كه جنبهاى مختلف موضوع را بررسى نكردهاند، به تأخير بيندازند. در ساير زمانها، رويكردى شهودتى تر را مار ييش مى گيرند و بسيار از احساسات تأثير مى يذيرند. فقدان ثبات در سبك مفهومسازى و تصميم گيرى، منجر به كاهش سودمندى تصميم ها و مفهومسازىهاى آنان

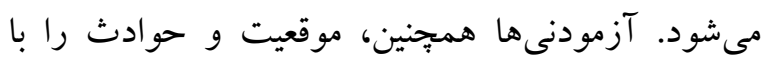

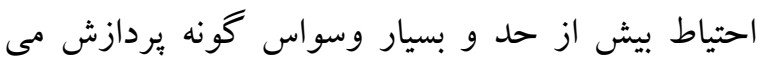
كنند و در تصميم گيرى خيلى سريع عمل مى كنند، در لتر نتيجه تصميمات با باسخهاى آنان به محيط اغلب نامناسب و ناكافى خواهد بود و تصميماتشان در اكثر مواقع با بال
تأثير نهايى آن شكست ها مى تواند اغلب ناكامى در يى

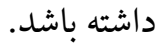

جدول Y نتايج نسبتها، درصدها و اشتقاق هاى آزمون را نشان مى دهد. در اين جدول، شاخص R نشانگر تعداد

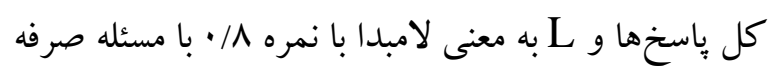
جويى در استفاده از منابع مرتبط است. به طور مثال آزمودنى ها بدون جمع آورى اطلاعات دقيق از محيط

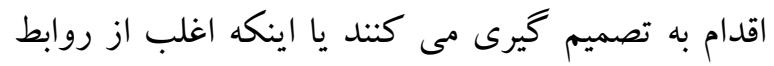
بارزش و تقويت كننده اجتناب مى كنند. اين موضوع باعث مى شود در تعاملات خود با محيط اغلب تجربه شكست و ناكامى داشته باشند و در نتيجه باعث استرس،

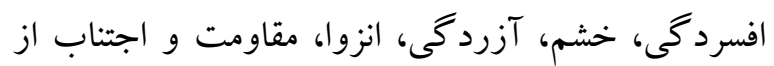

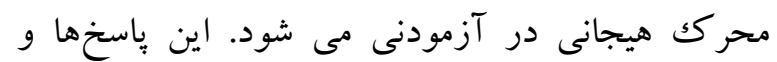

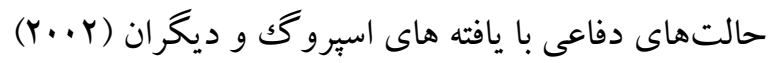

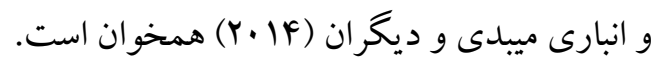
شاخص EB با نمره س: r نوع تجربه را نشان مىدهد كه نسبت دومتغيرحركت انسان (M) و مجموع وزنى باسخهاى رنغك است. شاخص eb با نمره 1 : r تجربه بايه رانشان مىدهد اين شاخص، نسبت پايين همه باسخهاى داراى تعيين كننده حركت غير انسان (m, FM) را با تمدين تعيين كننده هاى رنغك بى فام و سايه روشن مقايسه

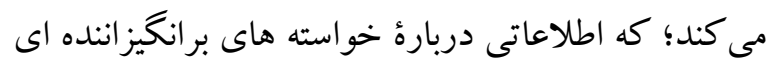

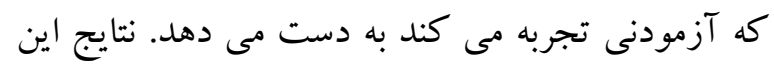
يافته ها نشان مى دهد كه آزمودنى ها در حال تجربه

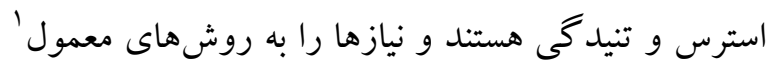

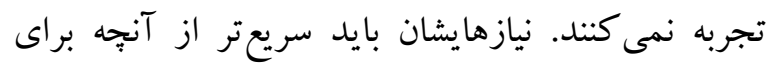

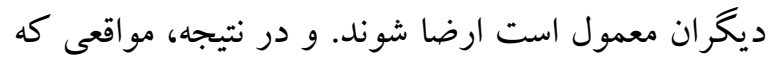

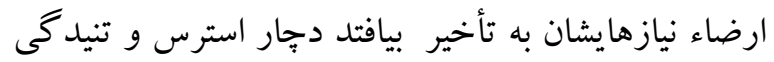

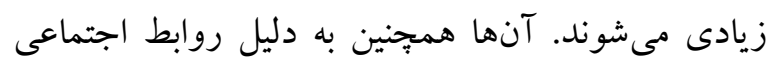

\footnotetext{
1. Typical
} 
وجود فعاليتهاى روان بريش گونه نيستند. متغيرهاى اين

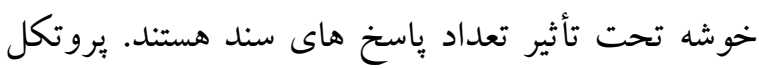
آزمودنى نسبت به ميانگين گروه نمونه هنجارى، بِاسخ هاى بيشترى ارائه كرده است كه نشان مى دهد واقعيت سنجى افراد معتاد به مواد مخدر تحت تأثير اشتغال ذهنىشان دجار نقص شده است. بدون ترديد برخى مشكلات در واقعيت سنجى آنها وجود دارد و اين مشكلات اجازه نمىدهند كه برداشت درستى از موقعيت و تجارب خود داشته باشند. آنان نسبت به صلاحيت شخصى خود دجار ترديد شده اند و نگگاه خودبزر گك بينانه اى ندارند بلكه برعكس، بر آورد آنها از اهميت شخصى خودشان، منفى است و از عزت نفسنفس پإينى برخوردارند. اين خود انتقادى و آشفتكى درونى با

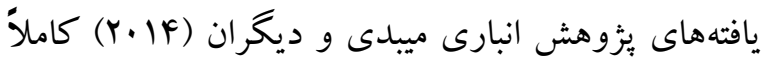
همخوان است ولى با وجود شخصيت خودشيفته در آزمودنى هاى همان تحقيق همخوان نيست.

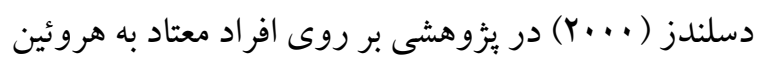

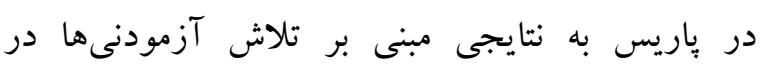

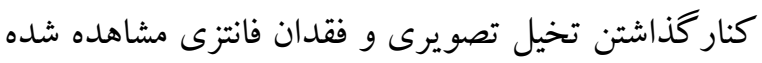
در آنها دست يافتند. اين يافته مخالف نتيجهى به دست آمده در يُزوهش حاضر است كه نشان مى دهد افر ادمعتاد به مواد مخدر به دليل عدم انعطاف يذيرى و دارا بودن تفكر عجيب و غريب در هر نوع موقعيت رفتارى و

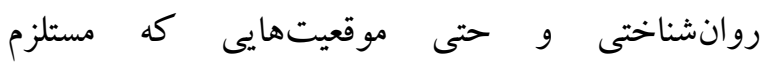
تصميم گيرىهاى بسيار مشابه است، به فانتى به عنى عنوان

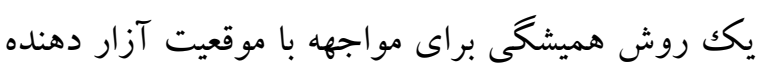
يناه مى برند. در تبيين اين يافته مىتوان جنين استدلال كرد كه تلاش آزمودنىهاى تحقيق دسلندز در كنار گذاشتن تخيل تصويرى نشانگر بى ثباتى در تفكر، تصميم گيرى و مفهوم سازى هاى اين آزمودنىها است. درنتيجه بيشتر مستعد خطا در قضاوت مىشوند و و به به ائ احتمال بيشترى به قضاوت و تصميم قبلى خود بشت
واقعيت موجود همخوانى ندارند. از نظر سادوكك و

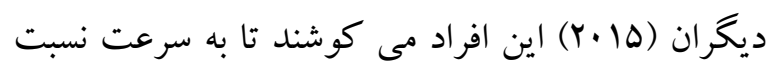
به آزردگىى حاصل از مزاحمت هاى افكار بيرامونى،

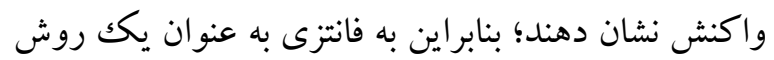

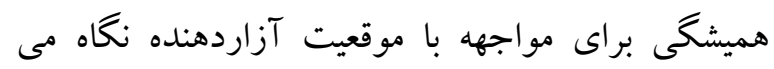

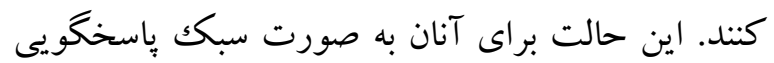
مزمن در آمده است. گاهى اين خصيصه را با عنوان سندرم

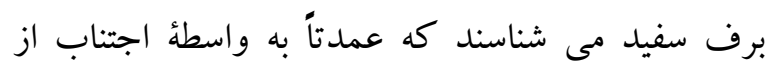
مسئوليت و تصميم گيرى تعريف مى شود.

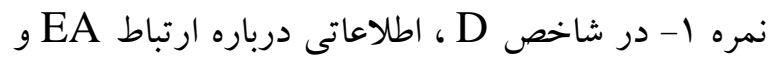
es

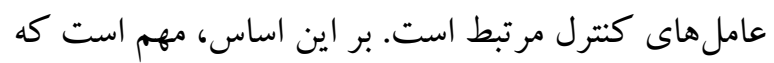

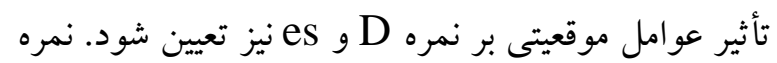

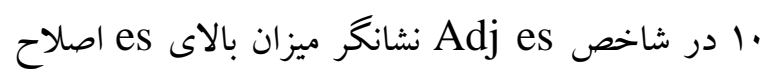
شده و نمره ا- در شاخص Adj D نيز نشان دهندهُ ميزان بايين نمره D اصلاحشده است. اين يافتها حاكى از اين

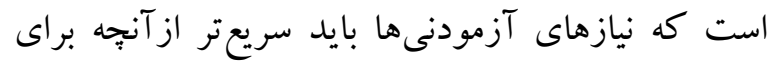

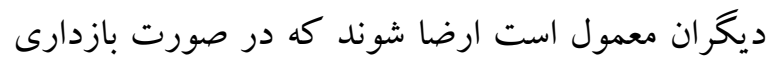
هيجانات و اجتناب از محرك هيجانى و در مواقعى كه

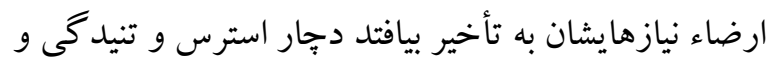
خشم زيادى مىشوند، هرجند كه در حفظ بيوند هيجانى و تعاملات بساوشى با ديكران محتاط هستند. آنها،

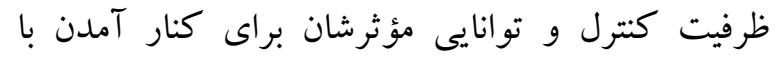
استرس از آنجه كه مورد انتظار است، كمتر است. و و

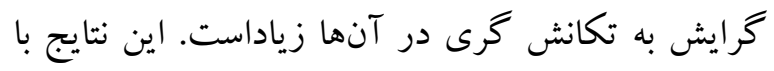

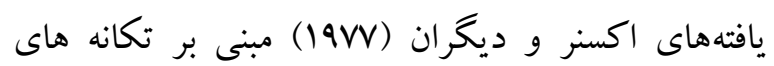

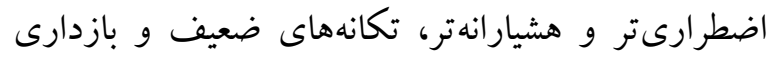

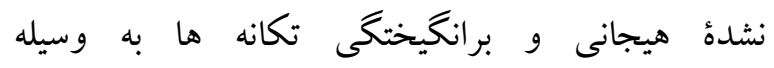
موقعيتهاى خارج از كنترل فرد، همخوان است. ياسخهاى كيفيت شكل منفى (FQX-) و نمايهى ادراكى - تفكر (PTI) نشانكر وجود اختلال در عملكرد شناختى مرتبط با واقعيت سنجى است كه بى شباهت به 
مى گيرند را بيش از اندازه وارسى مى كنند جرا كه تحت سلطةُ نياز به دقيق بودن قرار دارند. اين موضوع مى تواند دلايل متعددى داشته باشد از جمله، ممكن است بازتاب تمايل وسواس گونه آنان نسبت به كمال گرايى باشد كه موجب مى شود به طور غيرضرورى مجذوب جزييات

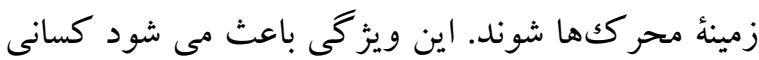

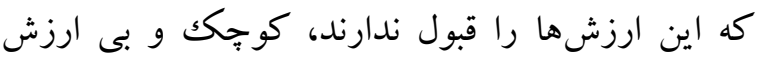

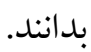

\section{نتيجه كيرى}

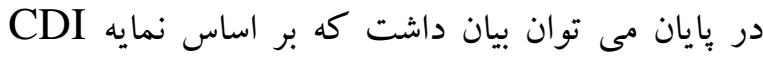

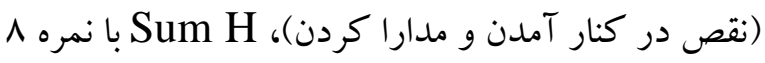

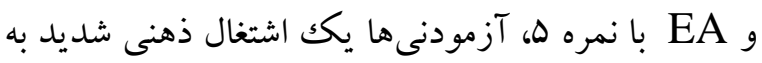
مردم و روابط بين فردى دارند و درك درستى از اين گونه

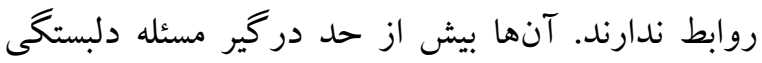
هستند و علاقه شديدى به مردم دارند اما جون بسيار

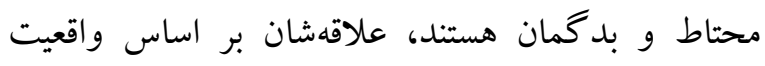
شكل نگرفته است و از روابط با ديخران انتظارات غيرواقع

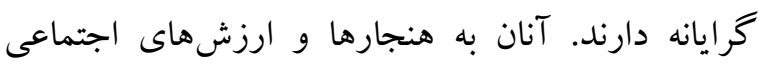
اهميت جندانى نمى دهند. اين موضوع به معناى اين نيست كه شخصيت ضداجتماعى دارند بلكه بيشتر به اين معنى است كه افرادى خاص هستند و جهان اطرافشان را متفاوت اما درست دركك مى كنند. بدين لحاظ از نظر ديخران افرادى نجسب يا گوشه گير شناخته مى شوند كه به نيازهاى ديخران بى توجه هستند. اين حالت مانع از

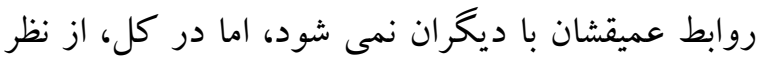

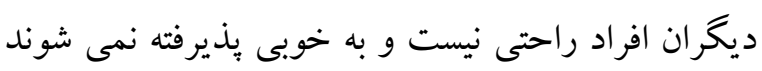

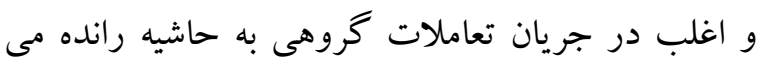
شوند. آنان احتمالاً كمتر به بلوغ اجتماعى رسيده اند و داراى نوعى منطق نايخته يا ضعيف هستند. اين استدلال

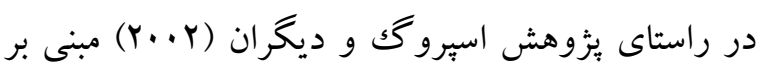
وابستخى دهانى و مدل روابط شىء در آزمودنى ها است.
مى كنند. عدم انعطاف يذيرى در آنان باعث شده كه

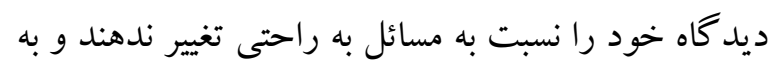

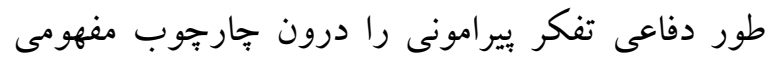
تفكر هدايت شده ادغام مى كنند و به باورها و ارزشهاى دهري خود بسيار بايبند هستند. اين مسئله هنغام روان درمانى

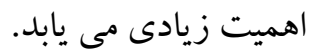

غيرقابل محاسبه بودن شاخص EBPer، شاخص Sum

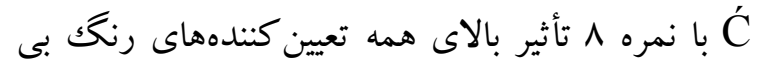
فام، SumT با نمره صفر تأثير بايين همه تعيين كنندههاى بافت، SumV با نمرهُ صفر تأثير بايين همدُ تعيين كننده هاى جشم انداز و SumY با نمرهُ صفر نيز تأثير وِايين همد تعيين كننده هاى سايه روشن را نشان مى دهد. اين يافته ها بيانكر بازدارى هيجانات در آزمودنى هاست. هين آنان در بسيارى از تبادلات روزمره در هنگًام مواجهه با هيجان

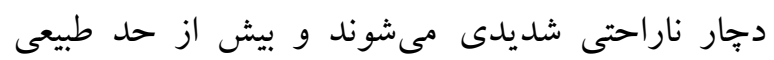

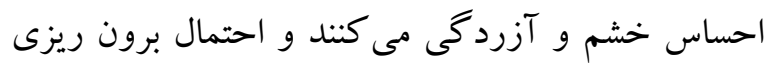
هيجانى در آن ها بالاست كه مشكلاتى در حوزه روابط إدى

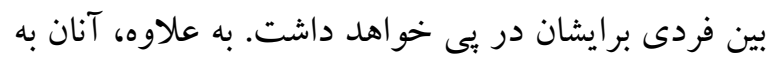

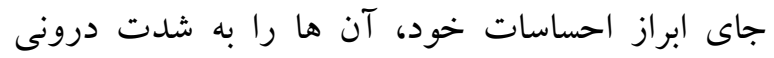
سازى مى كنند. درونىسازى بيش از حد احساسات در آنان منجر به انواع مشكلات از جمله اضطراب، ناراحتى، دئ،

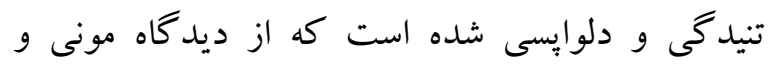
ديخران (199V) جهت رهايى از تنش به سمت مو ادمخدر

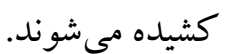

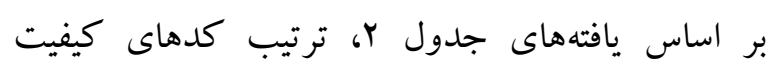

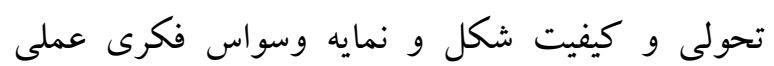
نشانه كيفيت يردازش ضعيف و ناقص افراد معتاد به مواد مخدر در موقعيتهاى ييجيده است. شيوه

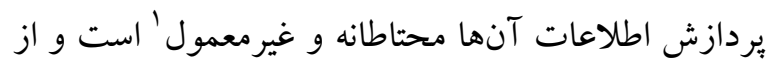
نظم خاصى بيروى نمى كند. اطلاعاتى كه آنان از محيط

${ }^{1}$. Atypical 
Anbari meybodi N, Talei pasand S, Rahimian Booger I. (2014). Personality Profile of MetAmphetamine dependent patients based on Rorschach Test. Joumal of mental Heealth Principles, 16, 3, 192-199.

Atkinson Rita L, Atkinson Richard C, Smith Edward E, Bem Daryl J, Nolen-Hoeksema Susan. (2014). Atkinson and Hilgard's Introduction to Psychology. Mohammad naghi Barahani and others. (persian Translator).Tehran:Roshd.

Bahrami H. (2018). Personality Projective Tests. Tehran: Allameh Tabatabai university press. Choca James P. (2013). The Rorschach Inkblot Test: An Interpretive Guide for Clinicians .Washington, D C: American psychological Association.

Choca James P, \& Bechtold Kathleen T. (2016). The Rorschach Inkblot Test in Practice, Washington, D C: American psychological Association.

Deslandes C, Gourarier L, Sanchez M \& Lowenstein W. (2000). The Rorschach's Test for Heroin Addicts Treated by Methadone: From Reality to Imaginary. Pub Med, 151, 61-64.

Exner IE, Wylie IR, Leura AV, \& parril T. (1977).

Some Psychological Characteristics of Prostitudes. Joumal of personality Assessment, 41,474-485.

Exner JE. (1974). The Rorschach: A Comprehensive System: Volume 1, New York: John Wiley \& sons,Inc.

Exner JE. (1986).The Rorschach: A Comprehensive System: Volume 1. Basic foundations. 2nd ed. New York: John Wiley \& sons, Inc.

Groth-Mamat G. (2018). Handbook of Psychological Assessment:Vol 2. Sharifi HP, Nikkhoo MR. (persian Translator). Tehran: sokhan.

Karimi Y. (2017). Personality Psychology. Tehran: Payam noor University.

Kkarimi dermani HR. (2017). Specific Grroups Rehabilitation Emphasized on Social Work Services. Tehran: Roshd.

Kohen B. (2018). Introduction to sociology. Tavassoli GA, Fazel R. (persian Translator). Tehran: Organization for the Study and Compilation of Humanities Books of Universities.

McKay E. (2017). The Inkblots: Herman Rorschach, His Iconic Test, and the Power of Seeing. Michigan: History of science, psychology.
بنابراين با توجه به نتايج جداول r و r و تحقيقات

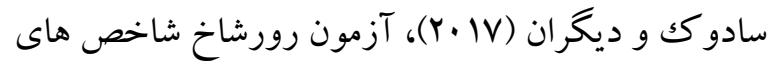
متفاوتى را براى متمايز كردن افراد معتاد به مواد مخدر از

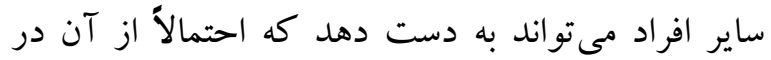
سنجش كاركرد اجتماعى، وضعيت اشتغال و فعاليت هاى بزهكارانه و نيز كاهش مصرف دارو مىتوان سود جست. اين بثوهش داراى سه محدوديت قابل توجه است: ا.فقدان هنجاريابى آزمون رورشاخ در بين معتادين به مواد مخدر در ايران، محدود بودن آن به يكك شهر مشخص از ايران و زمان بر بودن اجراى آزمون مخصوصاً در كار با افر اد شكاكك. r. نمره گذارى آزمون رورشاخ در اين تحقيق، بر اساس

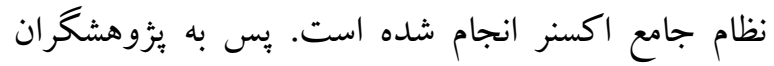
آتى توصيه مى شود كه در تحقيقات خود از اين نمره

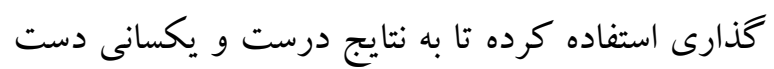

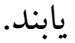
Г. همجِين، براى بررسى اعتياد آزمودنىها در اين تحقيق، از جنسيت زن و مرد به طور مختلط و از افراد \ا سال به

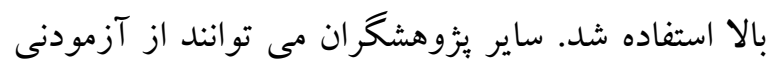
هاى همجنس جهت هنجاريابى در تحقيق خود استفاده كنند و در نهايت اينكه، جون نتايج اين تحقيق با تحقيقات بزوهشگران ديخر مبنى بر وجود شخصيت خودشيفته در معتادين، فقدان فانتزى مشاهدهده در آنها و تلاش در كنار كذاشتن اين تخيل، همخوان نبود؛ نياز به يثزوهشهاى بيشتر در اين خصوص احساس مى شود. سياسگز ارى از كليه كسانى كه در اين يُزوهش شركت داشته اند، تشكر و قدردانى مىشود. مقاله بركرفته از بايان نامه دوره كارشناسى ارشد مىباشد.

\section{References}


Mooney LA, Knox D, \& Schacht C. (1997). Understsnding Social Problems. New York: West publishing Co.

Parks CW, Jr, \& Hollon SD. (1988). Cognitive Assessment. In A S. Bellack \& M Hersen (Eds.), Behavioral Assessment: A Practical Handbook (pp.161- 212). New York: Pergamon press.

Rahmani F. (2006). Rorschach and Information Processing Deficiency in Depressed Patients. Journal of Iranian Psychologists: Vol 2. 7, 185193.

Rosenhan David L, Seligman Martin EP. (2016). Abnormal Psychology: Psychological Pathology. Seyed mohammadi Y. (Persian Translator). Publishing Arsabaran.

Sadock Benjamin J, Sadock Virginia A, Ruiz P. (2017). Synopsis of Psychiatry: Behavioral sciences / Clinical Psychiatry:Vol 1, 2. Rezaee F. (Persian Translator). Tehran: Arhmand.

Schiltz L. (2008). Extracting Specific Profiles in Two Clinical Subgroups of Patients Suffering from Addiction. Pub Med, 1, 75-90.

Schultz DP, Schultz SE. (2016). Theories of Personality. Seyed mohammadi Y. (Persian Translator). Tehran: Edit Publishing Institute.

Sedigh sarvestani R. (2011). Social Pathology (Sociology of Deviance). Tehran: Organization for the Study and Compilation of Humanities Books of Universities (OSC).

Sprohge E, Handler L, Plant DD, \& Wicker D. (2002). A Rorschach Study of Oral Dependence in Alcoholics and Depressives. Journal of personality Assessment, 79 (1), 142-160.

Trull Timothy J, Prinstein Mitchell J. (2018). Phares Clinical Psychology. Firozbakht M. (Persian Translator). Tehran: Roshd. 